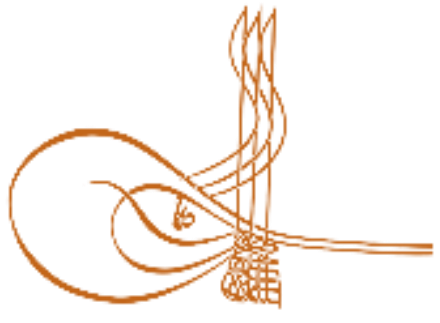

www.turkishstudies.net/social
Turkish Studies - Social Sciences

eISSN: $2667-5617$

Research Article / Araştırma Makalesi

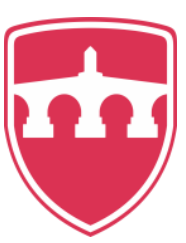

INTERNATIONAL

BALKAN

UNIVERSITY

Sponsored by IBU

\title{
Yerel Halkın Kültürel Mirası Korumaya Katılma Tutumu ve Turizmi Destekleme Davranışının Demografik Özelliklerine Göre İncelenmesi
}

\author{
Examining the Attitudes of Local People to Participate in Protecting Cultural Heritage and \\ Supporting Tourism Behavior According to Their Demographic Characteristics
}

\author{
Çetin Akkuş ${ }^{*}$ - Gülizar Akkuş**
}

\begin{abstract}
Although the function of protecting socially important tangible assets is often carried out by the state, the sensitivity or awareness of the local people living in the region makes a significant difference in the level of protection of cultural heritage. In the cases where the public has awareness of conservation and participate in conservation activities, great successes are achieved. Tourism activities play a leading role in achieving this success or especially in developing a conservation attitude. In this study, it was aimed to determine the knowledge level, thoughts on the protection of the area, the attitude towards participating in conservation activities and supporting tourism development of the local people living around Sarkaya Basilica Therma located in Sarıkaya district of Yozgat, which was included in the UNESCO World Heritage Temporary List in 2018. In addition to this, it is aimed to determine the difference of the attitude of participating in protecting cultural heritage according to the demographic characteristics of the people of Sarıkaya. Within the scope of the research, 273 people were reached and a questionnaire form consisting of 23 questions with closed ends and options was applied. As a result of the analysis made on the data obtained, it was found that the level of knowledge of the public regarding cultural heritage and the behavior that supports tourism development is quite high, but the attitude to participate in protection is low. In addition, significant differences were found in the attitudes of local people to participate in protection in terms of age, education, active work and the number of households.
\end{abstract}

\section{Structured Abstract: Introduction}

Tourism activities have a positive effect on preserving cultural heritage especially due to the economic contribution it provides to the public. It is a fact that protection activities for heritage elements are increased thanks to tourism development. However, there are still local people who do not support tourism and focus on

\footnotetext{
* Dr. Öğr. Üyesi, Kastamonu Üniversitesi, Turizm Fakültesi, Turizm ve Otel İşletmeciliği Bölümü Asst. Prof. Dr., Kastamonu University, Tourism Faculty, Tourism and Hospitality Management ORCID 0000-0002-6539-726X

cakkus@kastamonu.edu.tr

** Dr. Öğr. Üyesi, Kastamonu Üniversitesi, Turizm Fakültesi, Turizm Rehberliği Bölümü

Asst. Prof. Dr., Kastamonu University, Tourism Faculty, Tourism Guidance

ORCID 0000-0001-9262-2680

gakkus@kastamonu.edu.tr

Cite as/ Atıf: Akkuş, Ç., Akkuş, G. (2020). Yerel halkın kültürel mirası korumaya katılma tutumu ve turizmi destekleme

davranışının demografik özelliklerine göre incelenmesi, Turkish Studies - Social, 15(3), 887-904. https://dx.doi.org/10.29228/TurkishStudies.41753

Received/Geliş: 13 February/Şubat 2020

Accepted/Kabul: 25 April/Nisan 2020

Copyright $(\mathrm{C}$ INTAC LTD, Turkey

Checked by plagiarism software

Published/Yayın: 30 April/Nisan 2020

CC BY-NC 4.0
} 
the negative social, cultural or economic effects created by tourism. This situation greatly affects the protection of heritage elements in a destination planned to be opened to tourism or the course of tourism development in the region. Because it is the local people living with the resources in the destination that the tourist has visited for a few days and if they have not developed a conservation attitude, the heritage is damaged. For this reason, in order to prevent this situation, some informative activities are carried out to increase the awareness of the local people about cultural heritage, protection and tourism.

\section{Methodology}

In this study, it is aimed to determine the level of knowledge of the people of Sarıaya/Yozgat Province in Turkey who live in harmony with an important cultural heritage element included in the UNESCO World Heritage Temporary List, and their attitude towards participating in conservation and conservation activities and supporting tourism development. In addition, according to the demographic characteristics of the public, it is aimed to determine the different aspects of the behavior of participating in protection and supporting tourism. The research was carried out in April and May of 2019. 273 questionnaires were taken into consideration. In line with this purpose, the following research hypothesis has been put forward;

H1: The attitude of participating in protecting cultural heritage differs according to the demographic characteristics of the people of Sarikaya.

(H1a: Gender, H1b: Age, H1c: Education, H1d: Residence period in the district, H1e: Active working status, H1f: Job, H1g: Number of households, H1h: Income)

\section{Findings}

The ratio of those who positively regard the protection of the Basilica Therma is $97.8 \%$. On the other hand, the rate of those who know which policies regarding protection activities are followed is only $42.5 \%$. While the rate of those who are satisfied with these policies is $60.1 \%$, the rate of those who support them is $90.5 \%$. Accordingly, it can be said that the public is partially aware of the policies for the protection of cultural heritage, but it strongly supports the activities carried out even if they do not know.

The proportion of those who consider participating in any of the cultural heritage conservation activities carried out is only $30.8 \%$. This situation shows that the local people want to protect the cultural heritage values, but they do not want to take initiative in the realization of these activities. In summary, it can be said that the attitude of the public to participate in conservation activities is low.

The rate of those who think that they have any benefit to themselves or the district after the Basilica Therma is unearthed is $65.9 \%$, and the rate of those who think that it has benefited them or the district since it was included in the UNESCO World Temporary Heritage List is $60.8 \%$. From this, it can be concluded that entering the UNESCO World Temporary Heritage List has no tangible benefit to them. The rate of those who welcome the development of tourism in Sarıkaya is $97.2 \%$, and the rate of those who support the development of tourism in Yozgat is $97.8 \%$. With a very small margin, the proportion of those who support tourism development in Yozgat is relatively higher. However, it can be stated that the local people support tourism development significantly both in Sarıkaya and Yozgat. In addition, 88.3\% of respondents expect the government or local authorities to help or support these issues.

According to the responses (Table 2-Question 8) regarding the participation of local people in protecting the cultural heritage in the district, a difference analysis was made to compare their demographic characteristics and the results are given in Table 7. Since variables are categorical (yes-no, male-female, etc.) data, Chi-Square analysis was applied to observe the differences of these groups. Therefore, according to the attitude of the participants to support the protection of cultural heritage, there was no significant difference in terms of gender, residence time in the region, occupation and income. Accordingly, H1a, H1d, H1f and H1h hypotheses were rejected. However, significant differences were found in terms of age, education, active work and household numbers ( $\mathrm{p}=0.006$; 0.001; 0.018; 0.012). Consequently, H1b, H1c, H1e, H1g hypotheses are accepted.

\section{Conclusion and Suggestions}

As a result of the analyzes, it has been determined that the level of knowledge of the people of Sarıkaya about cultural heritage is high. In the study, it was determined that the attitude of Sarikaya people to support tourism development is quite high. The participants even stated that they can support tourism by cooking and 
selling local food, working in tourism businesses, producing and selling handcrafted products. With these results, it can be said that local people generally support tourism development and think that they can support tourism activities by producing local products and working in tourism-related jobs or businesses.

In the study, it was determined that the attitude of the people of Sarikaya to participate in the protection of cultural heritage (30.8\%) and the level of knowledge about the policies pursued in conservation activities $(42.5 \%)$ were quite low. From this point of view, it can be concluded that the people of Sarıkaya are not willing to participate in conservation activities because they do not have knowledge about conservation policies. The high budget protection activities carried out by central and local governments are important as well as the local people should be included in these activities and it should be felt that they are stronger stakeholders of the destination. Only in this way, it is possible to solve the problems that will arise during the protection activities more easily, and to absorb the damage that may arise due to the work done in a more moderate manner. Information sharing, which often seems insignificant, is very important in terms of continuing and accepting more successfully.

Also, in the research, significant differences were found in the behavior of the local people to participate in protection in terms of age, education, active work and the number of households. Especially people over 50 years of age who are not in active working life are found to have a higher desire to participate in protecting cultural heritage. The reason for this can be explained by the fact that people at the end of the active working age have more free time or that they are more sensitive to the social and cultural needs of the region they live in, thanks to the life experiences that occur in parallel with their age. However, it was found that the participants with five or more households differed from other groups in terms of participation in protection.

Keywords: Cultural heritage, Conservation, Participation in conservation, Tourism support, Sarkkaya Roman Bath.

Öz: Toplumsal açıdan öneme sahip somut varlıkları koruma işlevi sıklıkla devlet eliyle yürütülse de bölgede yaşayan yerel halkın duyarlılığ 1 ya da farkındalığı kültürel mirasın korunma düzeyinde önemli bir fark yaratmaktadır. Halkın koruma bilincine sahip olduğu ve korumaya yönelik faaliyetlere katıldığı örneklerde büyük başarılar sağlanmaktadır. Bu başarıya ulaşmada ya da özellikle koruma tutumu geliştirilmesinde ise turizm faaliyetleri öncü rol oynamaktadır. Bu araştırmada 2018 yılında UNESCO Dünya Mirası Geçici Listesi'ne girmiş Yozgat ili Sarıkaya ilçesinde bulunan Sarıkaya Roma Hamamı (Kral Kızı) çevresinde yaşayan yerel halkın kültürel mirasa ilişkin bilgi düzeyi, alanın korunmasına ilişkin düşünceleri, koruma faaliyetlerine katılma tutumu ve turizm gelişimini destekleme davranışlarını tespit etmek amaçlanmıştır. Bununla birlikte Sarıkaya halkının demografik özelliklerine göre kültürel mirası korumaya katılma tutumunun farklılığını belirlemek hedeflenmiştir. Araştırma kapsamında ilçede bir yıldan uzun süredir yaşayan 273 kişiye ulaşılarak, kapalı uçlu ve seçenekli 23 sorudan oluşan bir anket formu uygulanmıştır. Elde edilen verilere yapılan analizler neticesinde halkın kültürel mirasa yönelik bilgi düzeyinin ve turizm gelişimini destekleme davranışının oldukça yüksek olduğu ancak korumaya katılma tutumunun çok düşük olduğu tespit edilmiştir. Ayrıca yöre halkının yaş, eğitim, aktif çalışma ve hane halkı sayıları açısından korumaya katılma tutumunda anlamlı farklıklar saptanırken, cinsiyet, eğitim süresi, meslek ve gelir açısından anlamlı bir farklılık tespit edilememiştir.

Anahtar Kelimeler: Kültürel miras, Koruma, Korumaya katılma, Turizmi destekleme, Sarıkaya Roma Hamami.

\section{Giriş}

Bir neslin gelecek nesle bıraktığı miras, doğal ve/veya kültürel birtakım unsurlar taşır. Kültürel miras unsurları elle tutulabilir somut ya da soyut varlıkları içerir. Somut kültürel miras unsurları, insanların geçmişini görerek, dokunarak, hissederek keşfetmesini ve anlamasını sağlayan önemli değerlerdir. Bu değerler korunmaz ise zamanla birlikte aşınacak, yıpranacak ve yok olacaktır. Yok olmak, toplumun kültürünü anlamayı sağlayacak unsurların ortadan kalkması demektir. Toplumun kimliğinin, karakterinin kaybedilmesidir. 
Kültürel mirası korumaya ilişkin özellikle devlet eliyle merkezi yönetim ya da yerel yönetimler tarafından birçok faaliyet yürütülmektedir. Bunların başında somut kültürel miras unsurlarının bakımı, onarılması ve yenileme çalışmaları gelmektedir. Ancak bu faaliyetlere başlamak için geçen zaman ya da faaliyetlerin gerçekleştirilebilmesi için gereken zaman, miras unsurlarının daha dayanıksız hale gelmesine sebebiyet vermektedir. Bu süreçte özellikle henüz devlet eliyle koruma altına alınmamış miras unsurlarının bölgede yaşayan halk tarafından korunması büyük önem taşımaktadır. Halkın zaten uzun yıllardır ayakta kalmaya çabalayan ve bakıma ihtiyaç duyan bir esere karşı sorumlu hissetmemesi, duyarlı olmaması ve en vahimi tahrip etmesi, kültürün yavaş yavaş yok olmasına neden olmaktadır. Günümüzde koruma altına alınmış birçok alanda tarihi yapıların geçmişte yerel halk tarafından tahrip edildiği ya da kötü kullanıldığı bilinmektedir. Bunun en belirgin örnekleri UNESCO Dünya Miras Listesine girmeyi hak eden mühim eserler barındıran Kapadokya ve Ani Ören Yeri'nde görülmektedir (Eşitti, 2017: 142; Bilgili, 2018: 69). Ani Ören Yeri’ndeki birçok tarihi yapının yerel halk tarafından geçmişte ahır olarak kullanıldığı ya da Kapadokya'daki tarihi mekânlardaki çizimlerin, resimlerin ya da heykellerin tahrip edildiği bir gerçektir. Günümüzde bu alanlar korunmaktadır ancak resmi kanallar ile koruma işlemi gerçekleşinceye kadar da zarara uğramıştır. Bu tarz zararları önlemek ya da azaltmak namına bölge sakinlerinin kültürel miras unsurlarına karşı duyarlılığını arttırmaya yönelik bilgilendirici faaliyetler yürütülmektedir. Bu faaliyetler yanı sıra yöre halkına kültürel miras unsurları üzerinden ekonomik kazanç sağlamanın yolunu açan faaliyetlerin halkın miras farkındalığını daha hızlı bir biçimde değiştirdiği gözlenmektedir. Bu değişimin kilit aktörü ise turizm sektörüdür. Turizm faaliyetleri aracıllğıyla kültürel miras unsurları değerlendirilmekte, yani kullanılmakta aynı zamanda korunmaktadır. Ayrıca başlangıçta yalnızca ekonomik kazanç sağlama isteği ile hareket eden yerel halk, elindeki değerin kıymetini anlamakta ve kazancının devamlılığı için kültürel miras duyarlılığı artmaktadır (Akkuş, 2019: 163).

Bu araştırmada 2018 yılında UNESCO Dünya Mirası Geçici Listesi'ne alınmış Yozgat ilinde bulunan Sarıkaya Roma Hamamı çevresinde yaşayan yerel halkın kültürel mirasa ilişkin bilgi düzeyi, alanın korunmasına ilişkin düşünceleri, koruma faaliyetlerine katılma tutumu ve turizm gelişimini destekleme davranışlarını tespit etmek amaçlanmıştır. Bununla birlikte Sarıkaya halkının demografik özelliklerine göre kültürel mirası korumaya katılma ve turizmi destekleme davranışlarının farklılığını belirlemek hedeflenmiştir.

\section{Literatür Taraması}

Yerel halkın bölge kaynaklarını koruma ve yürütülen faaliyetleri destekleme durumunu tespite yönelik yerli ve yabancı yazında birçok araştırma yapılmıştır. İngilizce yazında konuya ilişkin ilk araştırmaların 2000 yılı öncesine (Infield, 1988; Newmark vd., 1993; Badola, 1998) dayandığı, ancak yoğunluğun bu tarihten sonra arttığı, 2010 yılı sonrasında ise azaldığ gözlenmiştir. Araştırmaların daha çok biyoloji ve coğrafya alanlarında gerçekleştirildiği, genellikle Güneydoğu Asya ve Afrika kıtası ülkelerinin hedef alındığı saptanmıştır. Araştırmalarda genellikle biyoçeşitlilik (Vodouhê vd., 2010), biyosfer rezervi (Young, 1999, Maikhuria vd., 2001; Silori, 2007) ya da milli park (Harada, 2003; Baral, 2005), yaban hayat1 sahası (Melkani, 2001; Kuriyan, 2002; Sekhar, 2003; Bandara ve Tisdell, 2003; Baral, 2005; Shrestha ve Alavalapati, 2006; Kideghesho, Røskaft ve Kaltenborn, 2007), sulak alan (Ambastha, Hussain ve Badola, 2007) gibi çeşitli korunan alanlara odaklanılmıştır. Türkçe yazında ise özellikle koruma davranışına değinilen ilk araştırmanın Sağlam ve Öztürk (2008) tarafından orman koruma faaliyetlerinin etkinliğinin artırılabilmesi için ihtiyaç duyulan orman köylüleri ile gerçekleştirildiği söylenebilir. Ancak bu araştırmanın da konusu olan yerel halkın kültürel mirası korumaya katılma ve turizmi destekleme tutumu üzerine gerçekleştirilmiş araştırmaların özellikle yabancı yazında doğal miras alanlarında gerçekleştirilen araştırmalar kadar yaygın olmadığı görülmüştür. Kültürel mirası korumaya dair yalnızca birkaç araştırmaya rastlanmıştır (Dizon vd., 2012; You vd., 2014). Bunların diğer araştırmalara nazaran son yıllarda yayınlandığı ifade edilebilir. Dizon vd. (2012) UNESCO Dünya Mirası Listesi kültürel peyzaj 
kategorisindeki ilk alan olan Ifugao Pirinç Teraslarına ilişkin gençlerin algı ve tutumlarını değerlendirmiştir. 100 öğrenci ile gerçekleştirilen anket çalışması sonucunda, gençlerin sadece dörtte birinin korunması önem arz eden alanda çalışmayı düşündüğü tespit edilmiştir. Öğrencilerin ortalama olarak pirinç teraslarına ilişkin olumlu algı ve tutumlara sahip olmalarına rağmen, çok azının teraslar ile ilgilenmeyi düşünüyor olması bir tehdit olarak değerlendirilmiştir. You vd. (2014) ise Güneydoğu Çin'deki Wuyishan Manzara Bölgesi kültürel ve doğal miras alanında ve çevresinde yaşayan yerel halkın korumaya katılma algı ve tutumlarını tespit etmeyi amaçlamıştır. Toplam sekiz köyde 160 haneden 304 geçerli anket verisi toplanmıştır. Yüksek eğitim seviyesine sahip bireylerin alanı koruma konusunda daha olumlu davrandığı, gelir düzeyi yüksek olan bireylerin korumaya katılma olasılıklarının daha yüksek olduğu tespit edilmiştir.

Aynı anahtar kelimeler ile yapılan Türkçe literatür taramasında, genellikle yerel halkın turizm algısına (Türkmen ve Dönmez, 2015; Boğan ve Sarışık, 2016; Ünal ve Yücel, 2018) ve bu algının turizme verdiği destek üzerindeki etkiye (Cengiz ve Kırkbir, 2007; Kiper ve Yılmaz, 2008; Özaltın Türker ve Türker, 2014; Belber ve Sözbilen, 2016; Karakaş ve Şengün, 2017; Erkılıç, 2019) odaklanıldığı gözlenmiştir. Bununla birlikte bölgede yaşayan öğrencilerin milli parka (Deniş, Genç, Demirkaya, 2008; Deniş ve Genç, 2010) ya da kültürel mirasa (Gümüş ve Adanal1, 2011; Güneş ve Alagöz, 2018; Turgut Gültekin ve Uysal, 2018) yönelik tutumlarına, halkın sürdürülebilir turizm gelişimi tutumlarına (Biçici, 2013; Arslan Ayazlar, 2017; Dağlı, 2018; Cavlak ve Toprak, 2018) dair araştırmalar da mevcuttur. Bazı araştırmalarda ise yerel halkın çeşitli turizm türlerine ilişkin algıları ve bakış açılarının değerlendirildiği tespit edilmiştir. Yöre halkının kırsal turizme (Güney ve Göller, 2016; Ayazlar, 2017), golf turizmine (Çetinkaya ve Dedeman, 2013), ekoturizme (Kavak, 2015; Surat, 2017) ve yavaş şehir hareketine (Çakııı, Yenipınar ve Benli, 2014) ilişkin algı ve tutumlarına yönelik araştırmalar tespit edilmiştir.

Yerel halkın kültürel mirası koruma ve turizmi destekleme tutumu üzerine ulaşılan araştırmalara ilişkin bilgiler paylaşılmıştır. Varnacı Uzun ve Somuncu (2011) Ihlara Vadisi'nde bulunan köylerde yaşayan halkın kültürel peyzajın korunmasına ve alanda yürütülen turizm faaliyetlerinin etkisine ilişkin görüşlerini değerlendirmiştir. Bu kapsamda 44 kişi ile derinlemesine görüşme gerçekleştirilmiştir. Bir y1l ardından Okuyucu ve Somuncu (2012) kültürel miras niteliği taşıyan geleneksel evleri sebebiyle Osmaneli ilçe merkezinde benzer bir araştırma yürütmüştür. 193 ilçe sakinine anket uygulanmıştır. İki araştırmada farklı ölçme teknikleri kullanılmasına rağmen halkın hem kültürel peyzajın ve mirasın korunması hem de turizm gelişimi konusunda olumlu görüşe sahip olduğu ve turizm işlerine katılmaya istekli olduğu tespit edilmiştir.

Sarı ve Bidav (2016) yöre halkının Munzur Vadisi Milli Parkı doğal ve kültürel çevresinin geliştirilmesi ve korunmasına yönelik farkındalığına odaklanmıştır. Saha araştırması milli parkın yakın olması sebebiyle Tunceli il merkezinde gerçekleştirilmiş ve 452 kişiye anket uygulanmıştır. Araştırma sonucunda parkın yeniden yapılandırılması için halkın destek verebileceği ve parkın korunması hususunda farkındalığa sahip olduğu belirlenmiştir. Giritlioğlu ve Sönmez (2018) ise yakın coğrafi bölgede bulunan farklı bir milli park olan Nemrut Dağı Milli Parkı ve çevresinde yaşayan yerel halkın kültür turizmine yönelik koruma ve gelişim algısına odaklanmıştır. Araştırma kapsamında park civarında yaşayan 500 kişiye ulaşılmış ve anket uygulaması gerçekleştirilmiştir. Sonuç olarak halkın genel anlamda kültür turizmi açısından parkın korunması ve geliştirilmesine ilişkin algı ve tutumlarının olumlu olduğu ortaya konmuştur.

Konuya ilişkin en güncel araştırma 2019 yılında Güneş vd. tarafindan gerçekleştirilmiştir. Araştırmada Konya il merkezinde yaşayan yerel halkın kültürel mirası koruma ve kullanmaya yönelik görüşlerini tespit etmek amaçlanmıştır. Araştırma kapsamında 483 il sakinine anket uygulanmıştır. Araştırma neticesinde halkın turizmi, kültürel mirasın korunması ve sürdürülebilirliğinin sağlanması açısından bir araç olarak kullanılabileceğini düşündüğü ve turizm faaliyetlerini desteklemede rol sahibi olabileceği tespit edilmiştir. Bu araştırmalar dışında yapılmış 
bazı araştırmalarda yerel halkın kültürel miras algısına odaklanılmış ancak araştırma içeriğinde halkın korumaya ilişkin düşünceleri de değerlendirilmiştir. Örneğin, İşçi, Güzel ve Ataberk (2018) Bergama ve Selçuk ilçelerinde yaşayan 841 kişi ile gerçekleştirdiği araştırmada, mekâna ve yerel halka bağlılığın kültürel miras algısını, bu algının da mirasın korunmasına ilişkin tutumu olumlu yönde etkilediğini tespit etmiştir. Uysal (2018) ise 404 kişilik bir örneklem ile İznik ilçesi yerel halkının kültürel mirasın turizm amaçlı kullanılmasına ilişkin olumlu algıya; kültürel mirasın korunarak turizm amaçlı kullanılmasında yerel yönetimlerin rolüne ilişkin olumsuz algıya sahip olduğunu tespit etmişsir.

\section{Araştırmanın Amacı}

Turizm faaliyetleri özellikle halka sağladığı ekonomik katkı sebebiyle kültürel mirası koruma yönünde olumlu bir etki yaratmaktadır. Hatta turizm gelişimi sayesinde miras unsurlarına yönelik koruma faaliyetlerinin arttırıldığı bir gerçektir. Ancak yine de turizmi desteklemeyen, turizmin yarattığı olumsuz sosyal, kültürel ya da ekonomik etkilere odaklanan yöre insanları bulunmaktadır. Bu durum turizme açılması planlanan ya da açılmış bir destinasyondaki miras unsurlarının korunmasını ve bölgedeki turizm gelişiminin seyrini büyük ölçüde etkilemektedir. Çünkü turistin birkaç günlüğüne ziyaret ettiği destinasyondaki kaynaklarla iç içe yaşayan yöre halkıdır ve onlar bir koruma tutumu geliştirmemişse mirasın tahribatı söz konusudur. Bu sebeple bu durumu önleyebilmek adına yöre halkının kültürel mirasa, korunmasına ve turizme dair farkındalığını arttırmaya yönelik birtakım bilgilendirici faaliyetler yürütülmektedir. Bu araştırmada ise UNESCO Dünya Mirası Geçici Listesi'ne alınmış önemli bir kültürel miras unsuru ile iç içe yaşayan halkın bu değere ilişkin bilgi düzeyi, bunu koruma ve koruma faaliyetlerine katılma tutumu ile turizm gelişimini destekleme davranışlarını tespit etmek amaçlanmıştır. Ayrıca halkın demografik özelliklerine göre korumaya katılma ve turizmi destekleme davranışlarının farklılaşan yönlerini belirlemek hedeflenmiştir. Bu amaca binaen aşağıdaki araştırma hipotezi ortaya konmuştur.

$H_{1}$ : Sarıkaya halkinın demografik özelliklerine göre kültürel mirası korumaya katılma tutumu farklllık gösterir.

$H_{\text {la: }}$ Sarıkaya halkının cinsiyetine göre kültürel mirası korumaya katılma tutumu farklılık gösterir.

$H_{l b}$ : Sarıaya halkının yaşına göre kültürel mirası korumaya katılma tutumu farklılık gösterir.

$H_{\text {Ic }}$ : Sarıkaya halkının eğitimine göre kültürel mirası korumaya katılma tutumu farklılık gösterir.

$H_{l d}$ : Sarıkaya halkının ilçedeki ikamet süresine göre kültürel mirası korumaya katılma tutumu farklllık gösterir.

$H_{l e}$ : Sarıkaya halkının aktif çalışma durumuna göre kültürel mirası korumaya katılma tutumu farklllık gösterir.

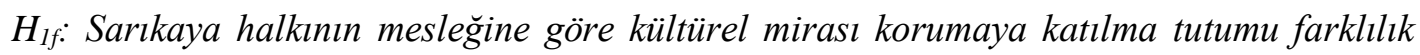
gösterir.

$H_{l g}$ : Sarıaya halkının hanehalkı sayısına göre kültürel mirası korumaya katılma tutumu farklılık gösterir.

$H_{l h}$ : Sarıkaya halkının gelirine göre kültürel mirası korumaya katılma tutumu farklılık gösterir.

Turkish Studies - Social, 15(3) 


\section{Araştırmanın Kapsamı}

Araştırma kapsamında 2018 yllında insanlık tarihinde önemli aşama(lar)1 gösteren bina, mimari/teknolojik yapı ya da peyzaj türünün olağanüstü örneği olmak (UNESCO, 2019) gerekçesiyle UNESCO Dünya Mirası Geçici Listesi'ne alınan Yozgat'ın Sarıkaya ilçesindeki yaklaşık iki bin yıllık Sarıkaya Roma Hamamı (Basilica Therma)'na odaklanılmıştır. Kültürel miras alanındaki ilk kazı çalışmaları 2010 yılında başlatılmıştır (NTV Haber, 2018). Öncesinde (Fotoğraf 1) 30 metre uzunluk ve 4.5 metre yükseklikte onar gözlü iki katlı bir kemer bulunan alandan birkaç oluk vasıtasıyla termal su akıtılmış ve bu su bölge halkı tarafından çeşitli şekillerde kullanılmıştır. Kazı çalışmaları ile birlikte 2014 yılında yarı olimpik yüzme havuzu gün yüzüne çıkarılmıştır. Alanın 2018 yılındaki son hali (Fotoğraf 2) ise aşağıdaki gibidir (Sarıkaya Kaymakamlığı, 2019a).

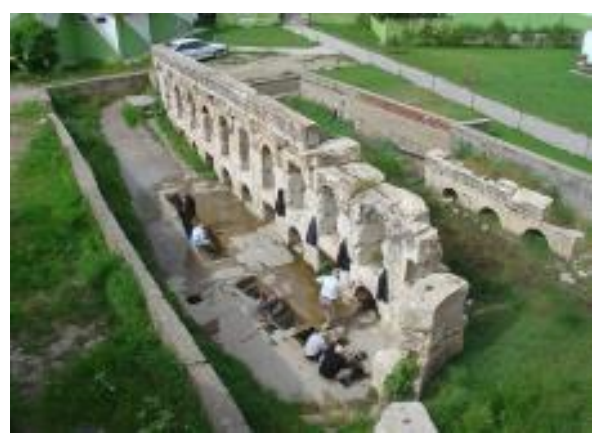

Fotoğraf 1

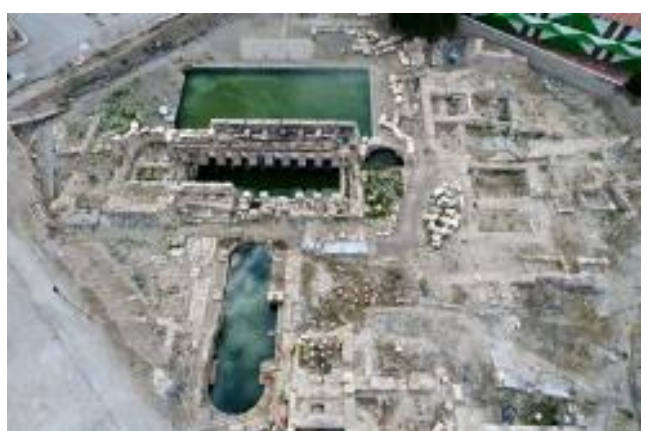

Fotoğraf 2

Tarih boyunca 45 derece sıcaklıktaki termal su ile doğal yolla beslenen hamamın birçok hastalığa iyi geldiği bilinmektedir. Hamamın dünyadaki tek benzerinin ise İngiltere'de bulunduğu ve yılda bir buçuk milyon turist tarafından ziyaret edildiği belirtilmektedir (NTV Haber, 2018). Sarıkaya ilçesi geçim kaynakları büyük oranda tarım ve hayvancılığa dayansa da mevcut miras unsuru sebebiyle önemli bir turistik değer taşımaktadır. Özellikle gelişmekte olan, az gelişmiş ya da kırsal alanlarda turizm, yarattığı gelir ve istihdam etkisi ile önemli bir kalkınma aracı olarak kabul edilmektedir. Roma Hamamı da Sarıkaya ilçesi halkına ekonomik katkı sağlayacak ve uzun vadede halkın refah seviyesinin yükselmesine sebebiyet verecek önemli bir değerdir. Günümüzde ziyaretçi sayısı nispeten sınırlı olmakla birlikte (Tripadvisor, 2020) özellikle merkezi ve yerel yönetimler tarafından gerçekleştirilen tanıtım faaliyetleri ile bu sayısının artması kaçınılmazdır. Özellikle gelişme aşamasındaki bir destinasyon için faydalı olabileceği düşüncesinden hareketle araştırma tek kaynağa ancak taşıdığı değer itibariyle büyük öneme sahip Sarıkaya ilçesinde gerçekleştirilmiştir.

\section{Örnekleme ve Veri Toplama Yöntemi}

Araştırmanın evrenini Sarıkaya ilçesinde yaşayan yerel halk oluşturmaktadır. Ancak evrenin tamamına ulaşılması maliyet ve zaman açısından mümkün olmadığı için örnekleme yoluna gidilmiştir. Evrenin ilgilenilen özellikler bakımından homojen olması sebebiyle tesadüfi olmayan örnekleme yöntemlerinden kolayda örnekleme yöntemi tercih edilmiştir.

Yozgat ili Sarıkaya ilçesi merkez nüfusu 18.090 (Sarıkaya Kaymakamlığı, 2020) olup, örneklem büyüklüğü hesaplama formülüne göre çalışmanın $\% 95$ güven aralığında toplam 377 kişiye yapılmasına karar verilmiştir (Altunışık vd. 2012: 137). Ancak ilçede en az bir yıl ya da daha uzun süreli ikamet eden 18 yaş üstü 290 kişiye ulaşılabilmiştir. İlçede ulaşılan yerel halktan kişiler, daha önce anket yapılacağını söyleyerek birtakım insanlar tarafından dolandırıldıklarını ifade etmiştir. Halkın anket yapan insanlara karşı olumsuz bir tutuma sahip olması sebebiyle araştırmada hesaplanan örneklem sayısına ulaşılamamıştır. Saha araştırması 2019 yılının Nisan ve Mayıs aylarında gerçekleştirilmiştir. Eksik doldurulan anketlerin elenmesi sonucu toplam 273 anket değerlendirmeye alınmıştır. 
Araştırmada veri toplama aracı olarak anket tekniği kullanılmıştır. Okuyucu ve Somuncu (2012) ile You vd.'nin (2014) çalışmalarından faydalanılarak kapalı uçlu 13 soru (evet-hayır), seçenekli dört soru (ilk üç soru altı seçenek, dördüncü soru dokuz seçenekli) ve demografik özellikleri tespite yönelik altı sorudan oluşan bir anket formu tasarlanmıştır (Tablo 1). Soruların kapalı uçlu ya da çoktan seçmeli sorulmasının en önemli sebebi daha önce yazarlar tarafından yapılmış benzer araştırmalarda (Akkuş, Akkuş ve Bayraktar, 2017a; Akkuş, Akkuş ve Bayraktar, 2017b; Akkuş ve Akkuş, 2019) yerel halkın görüşme yapmaya pek sıcak bakmadığının gözlenmiş olmasidir.

Ayrıca Sarıkaya Roma Hamamı halk arasında Kral Kızı Hamamı olarak bilindiği için (Ntv Haber, 2018) anket formunda Roma Hamamı yerine Kral Kızı Hamamı ifadesi kullanılmıştır. Halk arasında yaygın bir efsane sebebiyle hamam, Kral Kızı ismiyle anılmaktadır. Efsaneye göre, dönemin Roma kralının kızı bugünkü adı ile romatizma hastalığına yakalanır, cildinde yaralar çıkar ve gün geçtikçe tedavi edilemez hale gelir. Kral kızını son günlerini geçirmesi için bu termal su kaynağına gönderir. Bir müddet sonra tamamen iyileşen kız için kral buraya mermerden bir havuz yaptırır ve etrafını kesme büyük taşlarla çevirtir. Zamanla havuz çevresinde bir şehir oluşur (Sarıkaya Kaymakamlığı, 2019b).

\section{Bulgular}

Katılımcıların demografik özelliklerine ilişkin bulgular Tablo 1'de sunulmuştur. Buna göre araştırmaya tabi tutulan 273 katılımcının \%48,4'ü kadın iken \%51,6's1 erkektir. Yaş grupları incelendiğinde katılımcıların dörtte üçü $(\% 76,2)$ 18-39 yaş aralığındadır. Ayrıca popülasyonun yaklaşık \%80'ini lise mezunları ve üstü eğitim seviyesine sahip bireyler oluşturmaktadır. Katılımcıların yarısından fazlasının $(\% 56,5)$ bölgede ikamet sürelerinin 16 yıl veya daha fazla olduğu anlaşılmaktadır.

Tablo 1: Katılımcıların Demografik Özelliklerine İlişkin Bulgular

\begin{tabular}{|c|c|c|c|c|c|}
\hline & $f$ & $\%$ & & $f$ & $\%$ \\
\hline Cinsiyet & & & Ĕ̆itim Durumu & & \\
\hline Kadın & 132 & 48,4 & < İlköğretim & 57 & 20,9 \\
\hline Erkek & 141 & 51,6 & Lise & 62 & 22,7 \\
\hline Yaș & & & Lisans > & 154 & 56,4 \\
\hline$<30$ & 107 & 39,2 & Meslek & & \\
\hline $30-39$ & 101 & 37,0 & Kamu Çalışanı & 115 & 42,1 \\
\hline $40-49$ & 44 & 16,1 & İşçi & 63 & 23,1 \\
\hline $50>$ & 21 & 7,7 & Esnaf & 30 & 11,0 \\
\hline Hane Halkı Saytst & & & Çiftçi & 35 & 12,8 \\
\hline $1-2$ & 55 & 20,1 & Emekli & 8 & 2,9 \\
\hline $3-4$ & 132 & 48,4 & Diğer & 22 & 8,1 \\
\hline 5> & 86 & 31,5 & İkamet Süresi & & \\
\hline Aylık Hane Geliri & & & $1-5$ y1l & 62 & 22,7 \\
\hline $1-2200 \mathrm{TL}$ & 119 & 43,0 & 6-10 y1l & 37 & 13,6 \\
\hline $2201-5000 \mathrm{TL}$ & 96 & 35,4 & $11-15$ y1l & 20 & 7,3 \\
\hline $5001-7500 \mathrm{TL}$ & 26 & 9,6 & $16-20$ y1l & 40 & 14,7 \\
\hline $7501>$ & 32 & 12,0 & 20> & 114 & 41,8 \\
\hline
\end{tabular}

Geçim kaynakları göz önüne alındığında 115 kişinin $(\% 42,1)$ memur, 63 kişinin $(\% 23,1)$ işçi, 30 kişinin (\%11) esnaf, 35 kişinin (\% 12,8) çiftçi, 22 kişinin $(\% 8,1)$ diğer işlerde çalıştı ğ 1 , geriye kalan sekiz kişinin de $(\% 2,9)$ emekli olduğu saptanmıştır. Bu oranlar özellikle son on yılda 
nüfusunun \%30'dan fazlasını göç veren (TÜİK, 2019) Sarıkaya ilçesinin populasyonuyla uyumlu görünmektedir. Zira bu göçlerin önemli bir kısmının istihdam temelli olduğu söylenebilir. Buna karşın kamusal hizmet artışıla birlikte ilçeye naklolan eğitimli çalışanların sayısı göz önüne alındığında oranların merkez ilçe nüfusunu yansıttığ 1 ifade edilebilir. Hane halkı sayılarına bakıldığında da katılımcıların önemli bir kısmının (\%48) üç dört kişilik bir hane sayısı olduğu görülmektedir. Aylık gelir dağılımlarında ise \%43'lük bir kesim 2200 TL'nin altında gelire sahipken, 7500 TL üzerinde gelire sahip 32 kişi olduğu tespit edilmiştir.

Katılımcıların 13 kapalı uçlu soruya verdiği yanıtlara ilişkin bilgiler Tablo 2'de sunulmuştur. Buna göre anket yapılan 273 kişinin \%81,7'si UNESCO'nun görevinden haberdarken, \%79,9'unun da Kral Kızı Hamamı'nın UNESCO Dünya Geçici Miras Listesi'ne alındığını bildiği görülmektedir. Kral Kızı Hamamı'nı bir kültürel miras olarak görenlerin yüzdesi ise \%96,7 oranındadır. Bu bulgular, Sarıkaya halkının kültürel mirasa ilişkin bilgi düzeyinin yüksek olduğunu göstermektedir.

Tablo 2: Katılımcıların Kapalı Uçlu Sorulara Yönelik Değerlendirmeleri

\begin{tabular}{|c|c|c|}
\hline SORULAR & $\begin{array}{l}\text { EVET } \\
(\%)\end{array}$ & $\begin{array}{c}\text { HAYIR } \\
(\%)\end{array}$ \\
\hline 1.UNESCO'nun görevini biliyor musunuz? & 81,7 & 18,3 \\
\hline $\begin{array}{l}\text { 2.Kral Kızı Hamamı'nın UNESCO Dünya Geçici Miras Listesi'ne alındığını } \\
\text { biliyor musunuz? }\end{array}$ & 79,9 & 20,1 \\
\hline 3.Sizce, Kral Kızı Hamamı bir kültürel miras mıdır? & 96,7 & 3,3 \\
\hline 4.Siz bu mirasın korunmasına olumlu bakıyor musunuz? & 97,8 & 2,2 \\
\hline 5.Koruma faaliyetlerine ilişkin hangi politikaların izlendiğini biliyor musunuz? & 42,5 & 57,5 \\
\hline 6.Bu politikalardan memnun musunuz? & 60,1 & 39,9 \\
\hline 7.Gerçekleştirilen koruma faaliyetlerini destekliyor musunuz? & 90,5 & 9,5 \\
\hline 8.Herhangi bir koruma faaliyetine katılmayı düşünüyor musunuz? & 30,8 & 69,2 \\
\hline $\begin{array}{l}\text { 9.Kral Kızı Hamamı'nın, gün yüzüne çıkarıldıktan sonra size ya da ilçenize } \\
\text { herhangi bir faydası dokundu mu? }\end{array}$ & 65,9 & 34,1 \\
\hline $\begin{array}{l}\text { 10.Kral Kızı Hamamı, UNESCO Dünya Geçici Miras Listesi’ne alındığından } \\
\text { beri size ya da ilçenize herhangi bir fayda sağladı mı? }\end{array}$ & 60,8 & 39,2 \\
\hline 11.Bölgenizde turizm gelişimini olumlu karşılar mısınız? & 97,2 & 2,8 \\
\hline 12.Yozgat’ta turizm gelişimini destekliyor musunuz? & 97,8 & 2,2 \\
\hline $\begin{array}{l}\text { 13. Turizm alanında yapacağınız işlerde devletten ya da yerel yönetimlerden size } \\
\text { yardım etmelerini ya da destek olmalarını bekler misiniz? }\end{array}$ & 88,3 & 11,7 \\
\hline
\end{tabular}

Kral Kızı Hamamı'nın korunmasına olumlu bakanların oranı ise \%97,8'dir. Bu orandan çıarımla yöre halkının kültürel mirasa ilişkin koruma tutumunun oldukça yüksek olduğu ifade edilebilir. Buna karşın koruma faaliyetlerine ilişkin hangi politikaların izlendiğini bilenlerin oranı yalnızca $\% 42,5$ 'tir. Bu politikalardan memnun olanların oranı $\% 60,1$ iken, bunları destekleyenlerin oranı ise \%90,5'tir. Bu doğrultuda, halkın kültürel mirasın korunmasına yönelik politikalardan kısmen haberdar olduğu, ancak bilmese dahi yapılan faaliyetleri kuvvetle desteklediği söylenebilir.

Gerçekleştirilen kültürel mirası koruma faaliyetlerinden herhangi birine katılmayı düşünenlerin oranı yalnızca $\% 30,8$ 'dir. $\mathrm{Bu}$ durum yerel halkın kültürel miras değerlerinin korunmasını istemekle birlikte bu faaliyetlerin gerçekleşmesinde insiyatif almak istemediğini göstermektedir. Özetle halkın koruma faaliyetlerine katılma tutumunun düşük olduğu söylenebilir.

Kral Kızı Hamamı gün yüzüne çıkarıldıktan sonra kendilerine ya da ilçeye herhangi bir faydası olduğunu düşünenlerin oranı \%65,9, UNESCO Dünya Geçici Miras Listesi'ne alındığından beri kendilerine ya da ilçeye bir fayda sağladığını düşünenlerin oranı ise $\% 60,8$ 'dir. Buradan UNESCO Dünya Geçici Miras Listesi’ne girmenin kendilerine hissedilebilir bir faydasının olmadığı 
sonucu çıkarılabilir. Sarıkaya'da turizmin gelişmesini olumlu karşılayanların oranı \%97,2, Yozgat'ta turizmin gelişimini destekleyenlerin oran1 \%97,8'dir. Çok küçük bir farkla Yozgat'ta turizm gelişimini destekleyenlerin oranı nispeten daha yüksektir. Ancak yöre halkının hem Sarıkaya'da hem de Yozgat'ta turizm gelişimini önemli bir oranda desteklediği ifade edilebilir. Bu durum halkın turizm gelişimini destekleme davranışının oldukça yüksek olduğunu göstermektedir. Ayrıca cevaplayıcıların \%88,3'ü bu konularda devletten ya da yerel yönetimlerden yardım etmelerini ya da destek olmalarını beklemektedir.

Katılımcıların turizme ne tür bir destek verebilirsiniz sorusuna verdiği yanıtlar Tablo 3'te sunulmuştur. Buna göre, yerel halkın \% 41,4'ü yöresel yemeklerini pazarlayabileceği, \%40,3’ü turizm işletmelerinde çalışabileceği, \%39,2'si el işi ürünler üretip satabileceği, \%36,6'sı tarımsal ürünlerini pazarlayabileceği, \%21,2'si ev pansiyonculuğu yapabileceği, \%13,2'si ise farkl1 alternatifler düşünebileceklerini belirtmişsir.

Tablo 3: Katılımcıların Turizme Destek Verebileceği Faaliyetler

\begin{tabular}{lc}
\hline Faaliyetler & \% \\
\hline Yöresel yemeklerimi pazarlarım. & 41,4 \\
Turizm işletmelerinde çalışırım. & 40,3 \\
El işi ürünler üretip satarım. & 39,2 \\
Tarımsal ürünlerimi pazarlarım. & 36,6 \\
Ev pansiyonculuğu yaparım. & 21,2 \\
Diğer & 13,2 \\
\hline
\end{tabular}

Turizmin ilçe merkezinde yaratacağı pozitif etkilere yönelik katılımcı görüşleri Tablo 4'te verilmiştir. Buna göre cevaplayıcıların $\% 91,5$ 'i yerel halkın ekonomik gelirinin artacağını düşünmektedir. Turizm özellikle dezavantajlı bölgelerde halkın ekonomik refahını arttıracak önemli bir parametre olup, bu araştırmada da halk bu yönde görüş beyan etmiştir. Ayrıca katılımciların $\% 81$ 'i yerel kültürün canlanacağını, \%80,2'si kültürel mirasın öneminin anlaşılacağını düşündügünü belirtmiştir. $\mathrm{Bu}$ oranlar yerel halkın özellikle turizmin gelir getirici yönünü ön planda tutmakla birlikte yaşadıkları bölgenin sosyal hareketlilik kazanmasını da istediklerini göstermektedir. Katılımcıların yarısından fazlası ise koruma bilincinin artacağını $(\% 67,4)$, altyapının iyileşeceğini $(\% 56,7)$ ve ciddi koruma önlemlerinin alınacağını $(\% 53,8)$ düşündügünü belirtmiştir. Bu durum halkın turizm gelişimi ile birlikte miras unsurlarına yönelik koruma faaliyetlerinin de artacağını düşündüğünü yani turizm gelişiminin miras unsurlarının korunmasına katkı sunduğunu düşündüğünü göstermektedir.

Tablo 4: Katılımcıların Turizmin Yörede Yaratacağını Düşündüğü Pozitif Etkiler

\begin{tabular}{lc}
\hline Faaliyetler & \% \\
\hline Yerel halkın ekonomik gelirinin artması & 91,5 \\
Yerel kültürün canlanması & 81,0 \\
Kültürel mirasın öneminin anlaşılması & 80,2 \\
Koruma bilincinin artması & 67,4 \\
Altyapının iyileşmesi & 56,7 \\
Ciddi koruma önlemlerinin alınması & 53,8 \\
\hline
\end{tabular}

Yerel halkın, ilçe yönetiminin sorumluluğunda olduğunu düşündüğü fonksiyonlara ilişkin değerlendirmeleri Tablo 5’te yer almaktadır. Buna göre katılımcıların \%85,3'ü kültürel mirası ve 
ekolojik çevreyi korumanın, \%72,9'u yerel ekonomik gelişimi desteklemenin, \%60'1 eğitici uygulama ve çalışmaların, \%51,6'sı turizm faaliyetlerini standarda bindirmenin, \%44,7'si bilimsel eğitim ve araştırmanın ve $\% 40,1$ 'i ise turistlerin davranışlarını izlemenin ilçe yönetiminin sorumluluğunda olduğu kanaatindedir. Buradan çıkarımla Sarıkaya halkının özellikle kültürel mirasın korunması hususunda ilçe yönetimini sorumlu bulduğu söylenebilir. Bu bulgu, halkın gerçekleştirilen kültürel mirası koruma faaliyetlerine katılımlarının neden bu kadar düşük $(\% 30,8)$ olduğunu açıklayabilir.

Tablo 5. Katılımcılara Göre İlçe Yönetiminin Sorumluluğunda Olan Fonksiyonlar

\begin{tabular}{lc}
\hline Faaliyetler & $\mathbf{\%}$ \\
\hline Kültürel mirası ve ekolojik çevreyi koruma & 85,3 \\
Yerel ekonomik gelişimi destekleme & 72,9 \\
Eğitici uygulama ve çalışmalar & 60,0 \\
Turizm faaliyetlerini standarda bindirme & 51,6 \\
Bilimsel eğitim ve araştırma & 44,7 \\
Turistlerin davranışlarını izleme & 40,1 \\
\hline
\end{tabular}

Günümüz koşullarında şu anki en acil ihtiyaçları sorulduğunda, yöre halkının verdiği yanıtlar Tablo 6'da sunulmuştur. Bu doğrultuda yerel halkın en büyük ihtiyacının \%68,5 ile sermaye yetersizliğinden kaynaklandığı saptanmıştır. Bunu \%44,3 ile bilgi eksikliği izlemektedir. Sarıkaya halkının özellikle sermaye desteğin ve bunu optimum kullanma konusunda yönlendirilmeye ihtiyaç duyduğu tespit edilmiştir. Ortaya konacak uzun vadeli turizm planlarıyla bu durum aşılarak, halkın refahı sağlanabilir. Bunun dışında bölge halkının \%35,1'i düşük mahsul fiyatlarından, \%33'ü teknolojiyi kullanma yetersizliğinden, \%22,7'si mevcut enerji eksikliğinden, \%26,7'si elverişsiz trafikten, \%13,2'si çok katı yönetimden, \%0,03'ü alternatif seçeneklerden şikâyetçi olduklarını öne sürmüşlerdir. \%3,4'ü ise herhangi bir sıkıntı çekmediğini belirtmiştir.

Tablo 6: Katılımcıların Şu An Hayatındaki Acil İhtiyaçlar

\begin{tabular}{lc}
\hline Faaliyetler & \% \\
\hline Sermaye yetersizliği & 68,5 \\
Bilgi eksikliği ve ne yapacağını bilmemek & 44,3 \\
Düşük mahsul fiyatları & 35,1 \\
Teknolojiyi kullanma yetersizliği & 33,0 \\
Elverişsiz trafik & 26,7 \\
Mevcut enerji eksikliği & 22,7 \\
Çok katı yönetim & 13,2 \\
Herhangi bir sıkıntı çekmiyorum. & 3,4 \\
Diğer & 0,03 \\
\hline
\end{tabular}

Yerel halkın ilçede kültürel mirası korumaya katılımına ilişkin alınan yanıtlara (Tablo 2Soru 8) göre demografik özelliklerinin karşılaştırılmasına yönelik farklılık analizi yapılmış ve sonuçlar Tablo 7'de verilmiştir. Değişkenlerin kategorik (evet-hayır, erkek-kadın vb.) verilerden oluşması nedeniyle bu grupların farklılıklarını gözlemlemek için Ki-Kare analizi uygulanmıştır. Buna göre katılımcıların kültürel mirası korumayı destekleme tutumuna göre cinsiyet, bölgedeki ikamet süresi, meslek ve gelir açısından anlamlı farklı1ık bulunamamıştır. Bu doğrultuda $\mathrm{H} 1_{\mathrm{a}}, \mathrm{H} 1_{\mathrm{d}}$, $\mathrm{H} 1_{\mathrm{f}}$ ve $\mathrm{H} 1_{\mathrm{h}}$ hipotezleri reddedilmiştir. Buna karşın yaş, eğitim, aktif çalışma ve hane halkı sayıları 
açısından anlamlı farklıklar tespit edilmiştir ( $\mathrm{p}=0,006 ; 0,001 ; 0,018 ; 0,012)$. Bu nedenle $\mathrm{H} 1_{\mathrm{b}}, \mathrm{H} 1_{\mathrm{c}}$, $\mathrm{H} 1_{\mathrm{e}}, \mathrm{H} 1_{\mathrm{g}}$ hipotezleri kabul edilmiştir.

Tablo 7: Yerel Halkın Demografik Özelliklerine Göre Kültürel Mirası Korumaya Katılma Davranışına İlişkin Farklı1ık Analizi Sonuçları

\begin{tabular}{llll}
\hline & & Ki-Kare & Anlamlılık \\
\hline & Cinsiyet & 0,026 & 0,872 \\
Koruma & Yaş & 12,466 & $0,006^{*}$ \\
Faaliyetlerine & Eğitim & 14,771 & $0,001^{*}$ \\
Katılma & İkamet Süresi & 5,709 & 0,336 \\
& Aktif Çalışma & 5,551 & $0,018^{*}$ \\
& Meslek & 4,851 & 0,434 \\
& Hane Halkı Sayısı & 8,866 & $0,012^{*}$ \\
& Gelir & 6,374 & 0,095 \\
\hline
\end{tabular}

Yaş grupları açısından incelendiğinde, 30 yaş altı ve 30-39 yaş aralığının kültürel mirası korumaya yönelik en az destek veren gruplar olduğu görülmektedir (\%28 - \%22). 40-49 yaş aralığına gelindiğinde, bu oran $\% 45$ 'e çıkarken, en yüksek oran $\% 52$ ile 50 yaş üzeri katılımcılara aittir. Katılımcıların yaşları ilerledikçe korumaya katılma isteklerinin arttığı söylenebilir. Ayrıca aktif çalışma hayatının içinde olan katılımcılarda korumaya katılma oranı \%27 iken, aktif çalışmayanlarda bu oran \%42 olarak tespit edilmiştir. Bu durum aktif çalışma hayatındaki bireylerin kısıtlı boş zamanları sebebiyle korumaya katılma konusunda daha isteksiz davrandıklarını düşündürmektedir. Özetle, 50 yaş üzeri ve aktif çalışma hayatı içinde olmayan bireylerin korumaya katılmaya daha istekli olduğu ifade edilebilir.

Eğitim seviyeleri incelendiğinde daha ilginç sonuçlar ortaya çıkmaktadır. Katılımcıların eğitim seviyesi arttıkça korumaya katılma davranışlarında dramatik bir azalma görülmüştür. İlköğretim ve altı (okuryazar, ilkokul mezunu) bireylerde korumaya katılma isteği oranı \%51 iken, lise mezunlarında bu oran \%30,6'ya düşmekte, lisans ve üzeri eğitim seviyesine gelindiğinde ise bu oran \%23,4'e kadar gerilemektedir. Başka bir deyişle ilköğretim ve altı eğitim seviyesine sahip katılımcılarda her iki kişiden biri korumaya katılmaya destek verirken, lise mezunlarında her 3 kişiden biri, lisans ve üzeri eğitime sahip yalnızca 4 kişiden biri destek vermektedir. Hane halkı sayısı açısından incelendiğinde ise en yüksek katılımın beş ve üzeri hane halkı sayısına sahip katılımcılardan geldiği görülmüştür (\%43). Bu oranın yüksekliği hanede fazla sayıda bireyin bulunması sonucunda ailede kişi başına düşen sorumluluğun azlığı sebebiyle açıklanabilir.

\section{Sonuç}

Kültür, toplumların karakterini yansıtan önemli bir unsur olması sebebiyle korunması ve gelecek nesillere aktarılmas elzemdir. Aksi takdirde o milleti tanımlayan nitelikler ortadan kalkacak, dünya tek tipleşecek ve insanları seyahat etmeye iten en güçlü motivasyon kaynaklarından biri kaybolacaktır. Bu sebeple bir toplumun özellikle kendi kültürünü korumasının ne kadar önemli olduğu açıktır. Ancak mevzu ait olunan toplumun kendi kültürünü koruması olduğunda nispeten daha duyarlı olan toplumların, farklı irkların ya da toplulukların miras unsurlarına aynı anlayış, hassasiyet ya da korumacı tutumla yaklaşmadığı görülmektedir. Bu sebeple özellikle az gelişmiş ya da gelişmekte olan ülkelerde birçok miras niteliği taşıyan eser bilinçli olarak tahrip edilmiştir. Ancak turizmde global etik ilkeler bildirgesinde turizm eserlerinin, insanoğlunun ortak mirası olduğu açık bir şekilde belirtilmektedir. Bu sebeple herhangi bir ülke sınırı içerisinde tespit edilen farklı toplumlara ait miras unsurlarını korumak herkesin başlıca vazifesidir. 
İnsanlığın doğduğu, medeniyetlerin beşiği olan Anadolu topraklarında her gün yeni bir kalıntı, yeni bir eser gün yüzüne çıkarılmaktadır. Bunlardan biri de yaklaşık on yıldır kazıları devam eden ve 2018 yılında UNESCO Dünya Mirası Geçici Listesi'ne alınan Yozgat'ın Sarıkaya ilçesindeki iki bin yıllık Sarıkaya Roma Hamamı'dır. Bu kompleks yapı, Türk tarihine ait değildir, ancak dünya üzerindeki tüm eserlerde olduğu gibi bu miras unsurunu da insanlığa kazandırmak yapılması gerekli bir hizmettir. Bu eserin korunması, kazı çalışmalarının devamlılığı ve belki de en önemlisi halkın bu esere karşı duyarlılığı oldukça mühimdir. Bu sebeple bu araştırmada öncelikle halkın bu esere, tescilleyen kuruma ilişkin bilgi düzeyi, eserin korunmasına ve koruma politikalarına yönelik düşünceleri, koruma faaliyetlerine katılımı ve son olarak turizmi destekleme davranışına odaklanılmıştır.

Yapılan analizler sonucunda, Sarıkaya halkının kültürel mirasa ilişkin bilgi düzeyinin yüksek olduğu tespit edilmiş̧ir. You vd.'nin (2014) çalışmasında ise katılımcıların \%84,9'u bilgi düzeyine iliş̧kin kapalı uçlu soruya evet yanıtını vermiştir. Araştırmada Sarıkaya halkının turizm gelişimini destekleme tutumunun oldukça yüksek olduğu saptanmıştır. Hatta katılımcılar yöresel yemek yapıp satarak, turizm işletmelerinde çalışarak, el işi ürünler üretip satarak turizme destek verebileceğini ifade etmiştir. Varnacı Uzun ve Somuncu (2011), Okuyucu ve Somuncu (2012) ve Güneş vd. (2019) de benzer şekilde yerel halkın turizm gelişimine yüksek derecede olumlu baktığını tespit etmiştir. Bununla birlikte Okuyucu ve Somuncu (2012) halkın öncelikli olarak el işi ürünler üretip satarak ve turizm işletmelerinde çalışarak destek verebileceğini keşfetmiştir. Güneş vd. (2019) turizm tesislerinde çalışarak ve yöresel yemek yapıp pazarlayarak destek verebileceklerini saptamıştır. Varnacı Uzun ve Somuncu (2011) ise halkın özellikle yöresel ürünler, el işi ürünleri üretip satabileceğini, rehberlik ve ev pansiyonculuğu gibi işleri yapabileceklerini tespit etmiştir. Tüm araştırmalarda benzer sonuçlar elde edilmiş olup, yerel halkın genel olarak turizm gelişimini desteklediği ve sıralaması değişmekle birlikte yöresel ürünler ortaya koyarak ve turizmle ilgili işlerde ya da işletmelerde çalışarak turizm faaliyetlerine destek verebileceğini düşündüğü söylenebilir.

Araştırmada Sarıkaya halkının kültürel mirası korumaya katılma tutumunun $(\% 30,8)$ ve koruma faaliyetlerine ilişkin izlenen politikalara dair bilgi düzeyinin $(\% 42,5)$ oldukça düşük olduğu tespit edilmiştir. Buradan yola çıkarak, Sarıkaya halkının koruma politikaları konusunda bilgi sahibi olmaması sebebiyle koruma faaliyetlerine katılmaya istekli olmadığı sonucu elde edilebilir. Merkezi ve yerel yönetimler tarafından yürütülen yüksek bütçeli koruma faaliyetleri önemli olduğu kadar bölge halkının bu faaliyetlere dâhil edilerek, daha kuvvetli şekilde destinasyonun paydaşı olduğunun hissettirilmesi gerekir. Ancak bu sayede koruma faaliyetleri süresince çıkacak sorunların daha kolay çözülmesi, halkın yapılan çalışmalar sebebiyle ortaya çıkabilecek zararı daha 1lımlı bir şekilde absorbe etmesi sağlanabilir. Sıklıkla önemsiz gibi görünen bilgi paylaşımı, yapılan çalışmaların daha başarılı bir şekilde devam ettirilmesi ve kabul görmesi açısından oldukça önemlidir.

Ayrıca araştırmada, yöre halkının yaş, eğitim, aktif çalışma ve hane halkı sayıları açısından korumaya katılma davranışında anlamlı farklıklar saptanmıştır. Özellikle 50 yaş üzeri, aktif çalışma hayatı içinde olmayan kişilerin kültürel mirası korumaya katılma isteğinin diğer gruplara göre daha yüksek olduğu tespit edilmiştir. Bunun sebebi, aktif çalışma yaşının sonlarındaki kişilerin daha fazla boş vakitlerinin bulunması veya yine yaşları ile paralel olarak oluşan hayat tecrübeleri sayesinde yaşadıkları bölgenin sosyal ve kültürel ihtiyaçlarına karşı daha hassas olmaları ile açıklanabilir. Bununla birlikte beş ve üzeri hane halkı sayısına sahip katılımcıların korumaya katılma konusunda diğer gruplardan farklılaştığı saptanmıştır.

You vd. (2014) yüksek eğitim seviyesine sahip bireylerin kültürel mirası koruma konusunda daha olumlu davrandığını tespit etmiştir. Genel anlamda beklenti de katılımcıların eğitim seviyesi arttıkça korumaya katılma tutumu yükselmesidir. Ancak bu araştırmada tam tersi bir sonuç ortaya çıkmıştır. Sarıkaya halkından katılımcıların eğitim seviyesi arttıkça kültürel mirası korumaya yönelik hassasiyetin azaldığ 1 saptanmıştır. Bu durumun sebebi, uygulanan politikalara dair bilgi sahibi 
olamamaları ya da uygulanan politikaları beğenmemeleri kaynaklı olabilir. You vd. (2014) aynı zamanda gelir düzeyi yüksek olan bireylerin korumaya katılma olasılıklarının daha yüksek olduğunu belirtse de, bu araştırmada gelir açısından korumaya katılma tutumunda herhangi bir farklılık tespit edilememiştir.

Gelecek araştırmalarda, Sarıkaya halkından yüksek eğitim seviyesine sahip bireylerin korumaya katılma davranışlarının neden düşük olduğu farklı yöntemler ile özellikle nitel araştırma tekniklerinden derinlemesine görüşme tekniği ile kapsamlı bir şekilde araştırılabilir. Bu durumun altında yatan sebepler ortaya konduktan sonra özellikle eğitimli bireyleri de koruma faaliyetlerine dahil edebilmek ya da bu yönde bir algı geliştirebilmek amaçlı birtakım faaliyetlerde bulunulmalıdır. Aynı çalışma bölgedeki kazı çalışmaları tamamlandıktan ve alan tam anlamıyla turizme açıldıktan sonra tekrarlanarak sonuçlar karşılaştırılabilir. Bu sayede halkın bakış açısının hangi yönde değiştiği kolaylıkla tespit edilebilir.

\section{Kaynakça}

Akkuş, Ç., Akkuş, G. ve Bayraktar, Y. (2017a). Yerel halkın kültürel mirası korumaya katılma konusundaki algı ve tutumları: Erzincan-Kemaliye sit alanına yönelik bir araştırma, 1st International Congress on Social Sciences (USOS), 18-24 September 2017, Malaga-Spain.

Akkuş, Ç., Akkuş, G. ve Bayraktar, Y. (2017b). Somut kültürel mirası koruma çalışmaları: ErzincanKemaliye sit alan1, Turkish Studies, 12(35), 1-12.

Akkuş, Ç. (2019). Toplum temelli turizm (Ed. Şule AYDIN), Alternatif turizm, (s. 157-166). Erzurum: Atatürk Üniversitesi Açıköğretim Fakültesi Yayını.

Akkuş, G. ve Akkuş, Ç. (2019). Geçmişten günümüze geleneksel erzurum evleri, İstanbul: Kriter Yayınevi.

Altunışık, R., Coşkun, R., Bayraktaroğlu, S. ve Yıldırım, E. (2012). Sosyal bilimlerde araştırma yöntemleri SPSS uygulamalı, Geliştirilmiş 7. Baskı, Sakarya: Sakarya Yayıncılık.

Ambastha, K., Hussain, S. A. ve Badola, R. (2007). Resource dependence and attitudes of local people toward conservation of Kabartal wetland: A case study from the Indo-Gangetic plains, Wetlands Ecology and Management, 15, 287-302.

Arslan Ayazlar, R. (2017). Sürdürülebilir turizm tutum ölçeğinin (Sus-Tas) geçerlilik ve güvenilirlik çalışması, Seyahat ve Otel Işletmeciliği Dergisi, 14(2), 80-92.

Ayazlar, R. (2017). Kırsal turizmde yerel halkın tutumu, Gaziantep University Journal of Social Sciences, 16(1), 53-69.

Badola, R. (1998). Attitudes of local people towards conservation and alternatives to forest resources: A case study from the lower Himalayas, Biodiversity and Conservation 7, 1245-1259.

Bandara, R. ve Tisdell, C. (2003). Comparison of rural and urban attitudes to the conservation of Asian elephants in Sri Lanka: Empirical evidence, Biological Conservation, 110, 327-342.

Baral, N. (2005). Resources use and conservation attitudes of local people in the Western Terai landscape, Nepal, (Yayınlanmış Yüksek Lisans Tezi), Florida International University Environmental Studies, Miami, Florida.

Belber, B. G. ve Sözbilen, G. (2016). Nevşehir'in turistik ürünlerine olan talebin, şehrin kültürel miras unsurlarına etkisiyle ilgili yerel halk algıları, II. Uluslararası Nevşehir Tarih ve Kültür Sempozyumu, 2-4 Mayıs 2016, Nevşehir. 
Biçici, F. (2013). Datça yerel halkının sürdürülebilir turizm gelişimine ve turizm işletmelerine yönelik tutumları, Seyahat ve Otel İsletmeciliği Dergisi, 10(1), 19-36.

Bilgili, B. (2018). Kapadokya bölgesi Nevşehir yöresi kültürel varlıklarının bozulmalarına neden olan etmenler, Nevşehir Bilim ve Teknoloji Dergisi, 7(1), 60-74.

Boğan, E. ve Sarışık, M. (2016). Yerel halkın turizm faaliyetine yönelik görüş ve algılamalarının belirlenmesi üzerine Alanya'da bir araştırma, Kastamonu Üniversitesi İktisadi ve Ídari Bilimler Fakültesi Dergisi, Sayl:12, 325-342.

Cavlak, F. ve Toprak, L. (2018). Yeniçağa ilçesinin sürdürülebilir turizme açılmasında yerel halkın tutumu, Türk Turizm Araştırmaları Dergisi, 2(4), 14-25.

Cengiz, E. ve Kırkbir, F. (2007). Yerel halk tarafindan algılanan toplam turizm etkisi ile turizm desteği arasındaki ilişkiye yönelik yapısal bir model önerisi, Sosyal Bilimler Dergisi, 2007(1), 19-37.

Çakııı, C., Yenipınar, U. ve Benli, S. (2014). Yavaş şehir hareketi: Seferihisar halkının tutum ve algıları ile yaşam doyumları, Seyahat ve Otel İşletmeciliği Dergisi, 11(3), 26-41.

Çetinkaya, G. ve Dedeman, O. (2013). Golf turizmine yönelik yerel halkın algılarının belirlenmesi: Antalya/Belek örneği, Turizm ve Araştırma Dergisi, 2(1), 24-45.

Dağlı, Z. (2018). Sürdürülebilir turizmin gelişimine yönelik yerel halkın tutumlarını incelemeye ilişkin bir araştırma: Akçakoca destinasyonu, Seyahat ve Otel İşletmeciliği Dergisi, 15(3), 603-619.

Deniş, H. ve Genç, H. (2010). İlköğretim sekizinci sınıf öğrencilerinin yaşadıkları çevrede bulunan milli parklara yönelik tutumlarının bazı değişkenlere göre incelenmesi (Isparta ili örneği), Mehmet Akif Ersoy Üniversitesi Fen Bilimleri Enstitüsü Dergisi, 1, 9 - 25.

Deniş, H., Genç, H. ve Demirkaya, H. (2008). Milli parka yönelik tutum ölçeği geliştirilmesi, Gazi Ĕgitim Fakültesi Dergisi, 28(2), 95-107.

Dizon, J. T., Calderon, M. M., Sajise, A. J. U., Andrada II, R. T. ve Salvador, M. G. (2012). Youths' perceptions of and attitudes towards the Ifugao Rice Terraces, Journal of Environmental Science and Management, 15(1), 52-58.

Erkılıç, E. (2019). Yerel halkın turizm algısı ve turizmin geliş̧imine yönelik tutumları: Rize örneği, International Journal of Contemporary Tourism Research, 1, 66 - 82.

Eşitti, B. (2017). Ani Harabelerinin bölgesel kalkınma üzerindeki etkileri, Sosyal ve Beşeri Bilimler Araştırmaları Dergisi, 18(40), 129-147.

Giritlioğlu, İ. ve Sönmez, E. (2018). Kültür turizminin korunması ve geliştirilmesinde yerel halkın algısının belirlenmesi: Nemrut Dağı Milli Parkı Bölgesi'ndeki yerel halk üzerine bir araştırma, Uluslararası Sosyal Araştırmalar Dergisi, 11(58), 641-648.

Gümüş, N. ve Adanal1, R. (2011). The attitude and behavior of students in high school towards historical and cultural heritage in Buca (İzmir), Buca Eğitim Fakültesi Dergisi, 30, 87-102.

Güneş, E. ve Alagöz, G. (2018). Turizm eğitimi alan öğrencilerin kültürel miras tutumları üzerine bir araştırma, Adlyaman Üniversitesi Sosyal Bilimler Enstitüsü Dergisi, 10(29), 753-777.

Güneş, E., Pekerşen, Y., Nizamlıoğlu, H. F. ve Ünüvar, R. T. (2019). Konya ilinde sürdürülebilir turizm kapsamında kültürel mirasın korunması ve kullanımına yönelik yerel halkın görüşleri, Gümüşhane Üniversitesi Sosyal Bilimler Enstitüsü Elektronik Dergisi, 10(Ek Sayı), 1-14. 
Güney, D. ve Göller, V. (2016). Kırsal turizm konusunda yerel halkın yaklaşımının belirlenmesi: Misi Köyü örneği, Turizm Akademik Dergisi, 3(2), 25-36.

Harada, K. (2003). Attitudes of local people towards conservation and Gunung Halimun National Park in West Java, Indonesia, Journal of Forest Research, 8, 271-282.

Infield, M. (1988). Attitudes of a rural community towards conservation and a local conservation area in Natal, South Africa, Biological Conservation, 45, 21-46.

İşçi, C., Güzel , B. ve Ataberk, E. (2018). Mekana ve yerel halka bağl1lık, kültürel mirasa yönelik tutumu etkiler mi?, Balıkesir Üniversitesi Sosyal Bilimler Enstitüsü Dergisi, 21(40), 583605.

Karakaş, A. ve Şengün, H. İ. (2017). Yerel halkın turizm faaliyetlerine yönelik tutumları, Bartın Üniversitesi Iktisadi ve İdari Bilimler Fakültesi Dergisi, 8(15), 183-202.

Kavak, M. (2015). Edremit körfezi kuzey kıyllarında yerel halkın ekoturizme yönelik bilinç algısı ve tutumları. (Yayınlanmış Yüksek Tezi), Çanakkale Onsekiz Mart Üniversitesi Eğitim Bilimleri Enstitüsü.

Kideghesho, J. R., Røskaft, E. ve Kaltenborn, B. P. (2007). Factors influencing conservation attitudes of local people in Western Serengeti, Tanzania, Biodiversity and Conservation, 16, 2213-2230.

Kiper, T. ve Yılmaz, E. (2008). Şarköy-Kumbağ arasında kırsal kalkınmayı destekleyici turizmin olabilirliği ve yerel halkın rolü, Tekirdă̆ Ziraat Fakültesi Dergisi, 5(2), 159-168.

Kuriyan, R. (2002). Linking local perceptions of elephants and conservation: Samburu Pastoralists in Northern Kenya, Society and Natural Resources, 15, 949-957.

Maikhuria, R. K., Nautiyala, S., Raob, K. S. ve Saxenac, K. G. (2001). Conservation policy-people conflicts: A case study from Nanda Devi Biosphere Reserve a World Heritage Site, India, Forest Policy and Economics, 2, 355-365.

Melkani, V. K. (2001). Involving local people in biodiversity conservation in the KalakadMundanthurai Tiger Reserve, An overview, Current Science, 80(3), 437-441.

Newmark, W. D., Leonard, N. L., Sariko, H. I. ve Gamassa, D.-G. M. (1993). Conservation attitudes of local people living adjacent to five protected areas in Tanzania, Biological Conservation, 63, 177-183.

NTV Haber Resmi Web Sitesi (2018). "Yozgat'taki dünyanın en eski termal merkezi 'Kral Kızı' UNESCO ile dünyaya açılacak" https://www.ntv.com.tr/seyahat/yozgattaki-dunyanin-eneski-termal-merkezi-kral-kizi-unesco-ile-dunyaya-acilac,o_cnu6RUjU6EZT66Mbm6xg Erișim Tarihi: 01.10.2019

Okuyucu, A. ve Somuncu, M. (2012). Kültürel mirasın korunması ve turizm amaçlı kullanılmasında yerel halkın algı ve tutumlarının belirlenmesi: Osmaneli ilçe merkezi örneği, Ankara Üniversitesi Çevrebilimleri Dergisi, 4(1), 37-51.

Özaltın Türker, G. ve Türker, A. (2014). Yerel halkın turizm etkilerini algılama düzeyi turizm desteğini nasıl etkiler: Dalyan destinasyonu örneği, Electronic Journal of Vocational Colleges, 4(1), 81-98.

Sağlam, B. ve Öztürk, A. (2008). Orman koruma faaliyetlerinde etkinliğin artırılmasında orman köylüsü-ormancılık teşkilatı ilişkileri: Artvin Orman Bölge Müdürlüğü örneği, Kastamonu Üniversitesi Orman Fakültesi Dergisi, 8(2), 131-143. 
Sarı, C. ve Bidav, Y. (2016). Munzur Vadisi Milli Parkı'nda doğal ve kültürel çevrenin geliştirilmesi ve korunması üzerine yöre halkının farkındalığı, TÜCAUM Uluslararası Coğrafya Sempozyumu, 13-14 Ekim 2016, Ankara.

Sekhar, N. U. (2003). Local people's attitudes towards conservation and wildlife tourism around Sariska Tiger Reserve, India, Journal of Environmental Management, 69, 339-347.

Shrestha, R. K. ve Alavalapati, J. R. R. (2006). Linking conservation and development: An analysis of local people's attitude towards Koshi Tappu Wildlife Reserve, Nepal, Environment, Development and Sustainability, 8, 69-84.

Silori, C. S. (2007). Perception of local people towards conservation of forest resources in Nanda Devi Biosphere Reserve, North-Western Himalaya, India, Biodiversity and Conservation, $16,211-222$.

Surat, H. (2017). Artvin Yusufeli'nde yerel halkın ekoturizme yönelik alg1 ve tutumları, Journal of Forestry, 13(2), 9-19.

T.C. Sarıkaya Kaymakamlığı, "Roma Hamamı” (2019a). http://www.sarikaya.gov.tr/roma-hamami Erişim Tarihi: 05.10.2019.

T.C. Sarıkaya Kaymakamlığı, "Kral Kızı Hamamı Efsanesi” (2019b). http://sarikaya.gov.tr/kralkizi Erișim Tarihi: 05.10.2019.

T.C. Sarıkaya Kaymakamlığı, "Nüfus ve Dăğllmı” (2020). http://www.sarikaya.gov.tr/nufus-vedagilimi Erişim Tarihi: 08.04.2020.

Tripadvisor, "Eski Roma Hamami” (2020). https://www.tripadvisor.com.tr/Attraction_Reviewg3526341-d9863077-ReviewsBasilica_Therma_Eski_Roma_HamamI Sarikaya_Yozgat_Province.html Erişim Tarihi: 11.04.2020.

Turgut Gültekin, N. ve Uysal, M. (2018). Kültürel miras bilinci, farkındalık ve katılım: Taşkale Köyü örneği, Uluslararası Toplum Araştırmaları Dergisi, 8(15), 2030-2065.

Türkiye İstatistik Kurumu (TÜIK) (2020). "Adrese Dayalı Nüfus Kayıt Sistemi Sonuçları", https://biruni.tuik.gov.tr/medas/?kn=95\&locale=tr Erişim Tarihi: 08.04.2020

Türkmen, F. ve Dönmez, Y. (2015). Korunan alanların turizme açılmasına ilişkin yerel halkın görüşleri (Yenice örneği), Karabük Üniversitesi Sosyal Bilimler Enstitüsü Dergisi, 5(2), 189204.

UNESCO Resmi Web Sitesi (2019). “The Criteria for Selection”, https://whc.unesco.org/en/criteria Erişim Tarihi: 17.10.2019

Uysal, K. (2018). Kültürel mirasın turizm amaçlı kullanılmasında yerel halkın algl ve tutumlarının belirlenmesi: İznik örneği, (Yayınlanmış Yüksek Lisans Tezi), Balıkesir Üniversitesi Sosyal Bilimler Enstitüsü, Balıkesir.

Ünal, Ç. ve Yücel, B. (2018). Kırsal turizmin geliştirilmesi ve yönetilmesinde yerel halkın alg1 ve tutumları. Ödemiş/Birgi örneği, Doğu Coğrafya Dergisi, 23(39), 113-130.

Varnacı Uzun, F. ve Somuncu, M. (2011). Kültürel peyzajın korunması ve turizm ilişkisi bağlamında yerel halkın görüşleri: Ihlara Vadisi örneği, Ankara Üniversitesi Çevrebilimleri Dergisi, 3(2), 21-36.

Vodouhê, F. G., Coulibaly, O., Adégbidi, A. ve Sinsin, B. (2010). Community perception of biodiversity conservation within protected areas in Benin, Forest Policy and Economics, 12, 505-512. 
You, W.-B., He, D.-J., Hong, W., Liu, C., Wu, L.Y., Ji, Z.-R. ve Xiao, S.-H. (2014). Local people's perceptions of participating in conservation in a heritage site: A case study of theWuyishan Scenery District cultural and natural heritage site in Southeastern China, Natural Resources Forum, 38, 296-307.

Young, E. (1999). Local people and conservation in Mexıco's El Vizcaino Biosphere Reserve, The Geographical Review, 89 (3), 364-390. 